\title{
Blood viscosity increases the degree of coronary stenosis in coronary heart disease
}

\author{
Antonius Ferika Indrianto*, Indranila Kustarini Samsuria*, \\ and Kusmiyati Deddy Kurniawan**
}

\begin{abstract}
\section{BACKGROUND}

Endothelial dysfunction and associated increased blood viscosity (BV) play an important role in the formation of atherosclerosis during inflammatory processes. C-reactive protein (CRP) is a biomarker of inflammation with an active role in endothelial dysfunction and development of atherosclerosis that is marked by degree of coronary stenosis (CS). The purpose of this study was to determine the relationship of BV and CRP with varying degrees of CS among coronary heart disease (CHD) patients.
\end{abstract}

\section{METHODS}

This cross-sectional study involved 24 subjects taken consecutively among patients with CHD who underwent angiography. Blood viscosity levels were determined using an Ostwald viscometer, with reference limits of 1.5 to $1.72(\mathrm{cP})$. C-reactive protein was determined by turbidimetric immunoassay, with a normal reference value of $<3 \mathrm{mg} / \mathrm{L}$. Degree of CS was examined with angiography, where $0 \%=$ no stenosis; $<50 \%=$ nonsignificant stenosis; $>50 \%=$ significant stenosis. Data was analyzed using non-parametric Spearman correlation test.

\section{RESULTS}

There were 17 male and 7 female subjects, with mean age of $55.96 \pm$ 7.29 years. The angiography results were: non-significant stenosis in 2 subjects (8.3\%), significant stenosis in 22 subjects $(91.7 \%)$ and none with normal stenosis. Statistical analysis of the relationship of BV with degree of CS found a moderate significant positive relationship $(r=0.549$; $\mathrm{p}=0.005)$. A poor significant positive relationship was found between CRP and degree of CS $(r=0.481 ; p=0.017)$.

\section{CONCLUSION}

Blood viscosity increased the degree of CS in CHD patients. Therapy should target both BV-associated risk and angiographically evident stenosis.

Keywords: C-reactive protein, blood viscosity, degree of coronary stenosis, coronary heart disease
*Department of Clinical Pathology, Faculty of Medicine, Diponegoro University/dr.Kariadi Hospital **Department of Biochemistry, Faculty of Medicine, Diponegoro University/dr.Kariadi Hospital

\section{Correspondence:}

dr. Antonius Ferika Indrianto, SpPK

Jl. Diponegoro 213 Ungaran Kab.

Semarang

Mobile: +62812 2930293

Email: f3rry_ind@yahoo.co.id

Univ Med 2015;34:168-76

DOI: $10.18051 /$ UnivMed.2016.v35.168-176 pISSN: 1907-3062 / eISSN: 2407-2230

This open access article is distributed under a Creative Commons Attribution-Non Commercial-Share Alike 4.0 International License 


\section{Viskositas darah meningkatkan derajat stenosis koroner pada penderita jantung koroner}

\section{ABSTRAK}

\section{LATAR BELAKANG}

Peran penting dalam pembentukan aterosklerosis selama proses inflamasi berlangsung adalah terjadinya disfungsi endotel dan sangat berhubungan erat dengan peningkatan viskositas darah (VD). C-reactive protein (CRP) adalah biomarker inflamasi yang berperan aktif dalam disfungsi endotel, dan perkembangan ateroskeloris yg ditandai derajad stenosis koroner (DSK). Tujuan penelitian ini untuk menentukan adanya hubungan antara VD dan CRP dengan berbagai derajat stenosis koroner (DSK) pada penderita jantung koroner.

\section{METODE}

Penelitian ini dilakukan dengan pendekatan belah lintang. Dua puluh empat penderita penyakit jantung koroner yang menjalani angiografi yang diambil secara konsekutif. Kadar VD diperiksa menggunakan viskometer Ostwald dengan batas nilai rujukan 1,5-1,72 (cP).C-Reactive protein diperiksa dengan turbidimetric imunoassay dengan acuan normal $<3 \mathrm{mg} / \mathrm{L}$. Derajad Stenosis koroner diperiksa dengan angiografi, 0\% : tidak ada stenosis ; $<50 \%$ non significant stenosis; >50\% significant stenosis. Dilakukan uji korelasi non parametrik Spearman.

\section{HASIL}

Terdapat 17 subyek laki-laki dan 7 subyek wanita, yang rata-rata umurnya 55,96 7,29 tahun. Pemeriksaan angiografi didapatkan pasien yang non signifikan stenosis 2 subyek (8,3\%), signifikan stenosis 22 subyek (91,7\%) dan tidak didapatkan yang normal / tidak ada stenosis. Analisis hubungan VD dengan DSK didapatkan adanya hubungan yang bermakna dengan kekuatan sedang $(r=0,549 ; p=0,005)$. Terdapat pula hubungan yang bermakna antara CRP dan DSK dengan kekuatan lemah ( $r=0,481 ; p=0,017)$.

\section{KESIMPULAN}

Viskositas darah meningkatkan derajat derajat stenosis jantung koroner pada penderita jantung koroner. Pengobatan harus ditujukan pada risiko yang terkait VD maupun DSK yang terlihat pada pemerikssan angiografi.

Kata kunci : C-reactive protein, viskositas darah, derajad stenosis koroner, penderita jantung koroner

\section{INTRODUCTION}

Coronary heart disease (CHD) is a terrifying disease that is still a problem in both developed and developing countries. According to data of the World Health Organization (WHO), heart disease is the number one cause of mortality in the world. Sixty percent of all causes of deaths from heart disease is accounted for by ischemic heart disease. At least 17.5 million or $30 \%$ of global deaths are caused by heart disease, and this number is projected to be 23.6 million in the year 2030. ${ }^{(1)}$ Coronary heart disease in Indonesia causes the highest number of deaths, approaching $26 \%$ or 53.5 per 100.000 inhabitants. In addition to being the top-ranking cause of death, CHD also lowers the quality of life of the patients. ${ }^{(2)} \mathrm{CHD}$ starts with endothelial dysfunction and ends in atherosclerosis. Endothelial cells have an integral role in the vascular structure, hemodynamics, and hemostasis. Abnormalities of vascular hemostasis that occur in endothelial dysfunction result in abnormalities of vascular motor function, inflammation, and thrombosis. ${ }^{(3,4)}$

Blood viscosity is a parameter used in hemorheology. Hyperviscosity of the blood injures 
the endothelial wall and causes an inflammatory response in the large arteries, resulting in plaque formation and subsequent rupture. All of the above shows that blood viscosity is plays an important role in the holistic approach for prevention and early detection in connection with cardiovascular health. ${ }^{(5)}$ Many studies have been conducted on blood viscosity in connection with atherosclerosis or CHD. A number of these studies have indicated that hemorheological parameters play an important role in the pathogenesis and development of $\mathrm{CHD}^{(6)}$ and that there is a relationship between hemorheological abnormalities and CHD severity. These studies have also found that therapeutic interventions for normalizing blood rheology may reduce the incidence and/or progressivity of CHD, and that changes in hemorheological parameters that lead to hyperviscosity may result in occlusive thrombotic events. ${ }^{(7,8)}$

Atherosclerosis is not merely a disease connected with lipid deposition, since systemic inflammation plays an essential role in the initiation, progression, and destabilization of atheromas. ${ }^{(9)}$ A large number of inflammatory markers are known, such as $\mathrm{C}$-reactive protein (CRP). This acute phase protein is measured by the hs-CRP (high sensitivity C-reactive protein) method, which is sensitive and practical, with known cut off values. CRP is a better cardiovascular predictor than LDL cholesterol and several other inflammatory markers. The CRP concentration is raised in infections, inflammation, or trauma. ${ }^{(10,11)}$ The role of CRP in evaluating the risk of cardiovascular disease is understandable, since it is a reflection of all pathologic mechanisms of CHD, being increased in chronic infections, inflammation, and atherosclerosis. ${ }^{(12)}$

There have been many studies conducted on the relationship of CRP and atherosclerosis or CHD. Several of these studies found a significant positive correlation between coronary artery stenosis and CRP concentration, where increased CRP concentration was accompanied by degree of stenosis. ${ }^{(13)} \mathrm{CRP}$ concentration is also associated with severity of coronary heart disease as detected on angiography and supports the hypothesis of a cause-and-effect relationship between the acute phase reaction and the pathogenesis of coronary artery atherosclerosis. ${ }^{(14,15)}$

Blood viscosity is a basic biological parameter affecting the macro- and microcirculation. Increased blood viscosity causes injury to the endothelial cell wall, thus interfering with endothelial function, and playing a role in the inflammatory process. ${ }^{(16)} \mathrm{CRP}$ is an acute phase protein and an inflammatory marker that is actively involved in endothelial dysfunction and the formation and development of atherosclerotic plaques. ${ }^{(17)}$ The study of Lee et al. ${ }^{\left({ }^{8}\right)}$ showed an association between hemorheological abnormalities (blood viscosity, erythrocyte aggregation) and severity of coronary artery disease. Chatzizisis et al. ${ }^{(18)}$ showed a role for endothelial stress wounds in atherosclerosis and vascular remodelling. Toth et al. ${ }^{(19)}$ found changes in hemorheological parameters in CHD. Hasnat et al. ${ }^{(20)}$ concluded that there is an association in patients with CHD between the concentration of highly sensitive $\mathrm{C}$ reactive protein (hs-CRP) and CHD severity in comparison to controls. ${ }^{(20)}$

Atherosclerotic plaques, in addition to being a disease of lipid deposition, also have a role in systemic inflammation as their main key, and may be expected to predict the early stages of coronary stenosis. In view of the above, the objective of the present study was to determine the relationship between blood viscosity as hemorheological parameter and CRP as inflammatory marker in patients with coronary artery stenosis.

\section{METHODS}

\section{Design of the study}

This study used a cross-sectional approach and was conducted from January until March 2014 in the outpatient and inpatient departments of the Cardiac Disease Unit, dr. Kariadi Central Hospital, Semarang. 


\section{Study subjects}

The study subjects were recruited from the cardiac outpatient and inpatient units of dr. Kariadi Central Hospital, Semarang. The subjects were selected by consecutive nonrandom sampling among patients with CHD who had undergone angiography and were screened by the inclusion and exclusion criteria. A total of 24 subjects were included, with the sample size $\mathrm{n}$ calculated according to the formula for comparison of 2 proportions:

$$
\left[\frac{(\mathrm{Z} \alpha+\mathrm{Z} \beta)^{2}}{\{0.5 \ln [(1+\mathrm{r}) /(1-\mathrm{r})]\}^{2}+3}\right]
$$

Where $\mathrm{Z} \alpha=1.96$ (level of significance), $\mathrm{Z} \beta=$ 1.28 (power of the study $=90 \%$ ), $r=0.64,{ }^{(26)}$ giving the total sample size of 21.3 or 22 . To anticipate possible drop outs, the sample size was increased by $10 \%$, so that the final sample size was 24.

The inclusion criteria for the study subjects were males or females, with normal body temperature, agreeing to participate in the study by signed informed consent, having normal serum SGPT (for determining normal liver function) and normal hemoglobin $(\mathrm{Hb})(>13 \mathrm{~g} /$ $\mathrm{dL}$ for males and $>12 \mathrm{~g} / \mathrm{dL}$ for females). The exclusion criteria were patients with a history of trauma or surgery; lipemia, jaundice, and hemolysis; pregnancy, dehydration, smokers, and $\mathrm{CRP} \geq 10 \mathrm{mg} / \mathrm{L}$.

\section{Laboratory analysis}

From the patients meeting the inclusion and exclusion criteria, fasting blood samples were drawn from the median cubital vein, using vacutainers filled with $5 \mathrm{ml}$ EDTA anticoagulant, for determination of blood viscosity and CRP within 3 hours of collection. ${ }^{(21)}$ Determination of blood viscosity was by means of an Ostwald viscometer, in which the blood sample in the Ostwald tube descends by gravitation. The time of descent was recorded with a stopwatch. ${ }^{(22)}$ The viscosity of the liquid was determined by measuring the time needed by the liquid to pass by gravitation between two marks on the Ostwald viscometer. The flow time of the tested liquid was compared with the time needed by a liquid with known viscosity (usually water) to pass by gravitation between the two marks on the Ostwald viscometer. A clean viscometer was filled by pipetting the test liquid and aspirating with the pushball past the two marks. The pushball was released to allow the liquid to drop from the first to the second mark, the resulting time being recorded by stopwatch. The viscosity coefficient was then expressed in SI units (Systeme International) as $\mathrm{Ns} / \mathrm{m}^{2}=$ Pa.s (pascal second). The unit centimeter gram second (CGS) for the SI viscosity coefficient is dyn.s/cm ${ }^{2}=$ poise $(\mathrm{P})$. Viscosity is also frequently expressed in centipoise (cP). $1 \mathrm{cP}=1 / 100 \mathrm{P}^{(23,24)}$

The CRP concentration was determined by the hsCRP method, using the particle enhanced turbidimetric immunoassay (PETIA). The serum sample was reacted in a cuvette with anti-CRP antibody (abCRP), antimicrobial buffer and polyethylene glycol buffer, the reactants becoming turbid at $37^{\circ} \mathrm{C}$. The resulting turbidity is a measure of the CRP concentration, as determined by the bichromatic rate technique (340 and 700 $\mathrm{nm})$. The results of the test are shown on a monitor, and the test takes 20 minutes to perform. Other methods for CRP determination are based on nephelometry and turbidimetry, which are applied in automated analysis. The reference value of CRP is $<3 \mathrm{mg} / \mathrm{L} .{ }^{(25)}$ Angiography is the gold standard for determining the degree of coronary stenosis. The finding of minimal stenosis in one coronary artery, expressed as $0 \%$ stenosis, indicates a normal coronary without stenosis. If the stenosis is $<50 \%$ of the luminal diameter, this indicates a non significant stenosis, while a stenosis of $\geq 50 \%$ of the luminal diameter indicates significant stenosis. ${ }^{(26)}$

\section{Data analysis}

The non parametric Spearman test was used to determine the relationship between blood viscosity and coronary stenosis and the relationship between CRP and coronary stenosis. 
Table 1. Characteristics of study subjects $(n=24)$

\begin{tabular}{lccc}
\hline \multicolumn{1}{c}{ Characteristic } & Mean \pm SD & $\begin{array}{c}\text { Median } \\
\text { (min; max) }\end{array}$ & n (\%) \\
\hline $\begin{array}{l}\text { Age (years) } \\
\text { Gender }\end{array}$ & $55.96 \pm 7.29$ & & \\
$\quad$ Male & & & $17(70.8 \%)$ \\
Fem ale & & & $7(29.2 \%)$ \\
Age by gender (years): & $55.2 \pm 7.3$ & \\
Male & $57.7 \pm 7.5$ & & \\
Female & $5.05 \pm 0.72$ & & \\
Blood visc osity (cP) & $3.38 \pm 2.45$ & & \\
C-reactive protein/CRP (mg/L) & & & \\
Degree of stenosis(\%) & & & \\
\hline
\end{tabular}

Significance was set at $\mathrm{p}<0.05$. The test indicates a very weak correlation, if $r=0.00-0.25$; a weak correlation if $r=0.25-0.50$; a moderate correlation if $r=0.50-0.75$; a strong correlation if $r>0.75$ and a very strong correlation if $r=0.80-1.00 .{ }^{(27)}$

\section{Ethical clearance}

This study obtained ethical clearance under no. 462/EC/FK/RSDK/ 2013.

\section{RESULTS}

With regard to subject characteristics, the youngest subject was 37 years old and the oldest 70 years (Table 1). Mean age of the subjects was $55.96 \pm 7.29$ years. The number of study subjects was 24 , consisting of 17 males (70.8\%) and 7 females $(29.2 \%)$. When the age was grouped according to gender, the youngest age for males was 37 years and the oldest 65 years. Among the female subjects, the youngest age was 49 years and the oldest 70 years. On the basis of degree of stenosis, there were 2 subjects $(8.3 \%)$ with nonsignificant stenosis. Significant stenosis was found in 22 subjects (91.7\%) and no study subjects were found with normal stenosis $(0 \%)$.

On statistical analysis, the correlation between blood viscosity and degree of stenosis was positively significant and of medium strength $(r=0.549 ; p=0.005)$. This signifies that increases in blood viscosity will be accompanied by increasingly severe stenosis. From the scatter plot (Figure 1), an increasing trend may be seen between degree of stenosis and blood viscosity.
A significant positive correlation was also found after statistical analysis of the relationship between CRP and degree of coronary stenosis, the correlation being of low strength $(\mathrm{r}=0.481$; $\mathrm{p}=0.017$ ). This indicates that increases in CRP

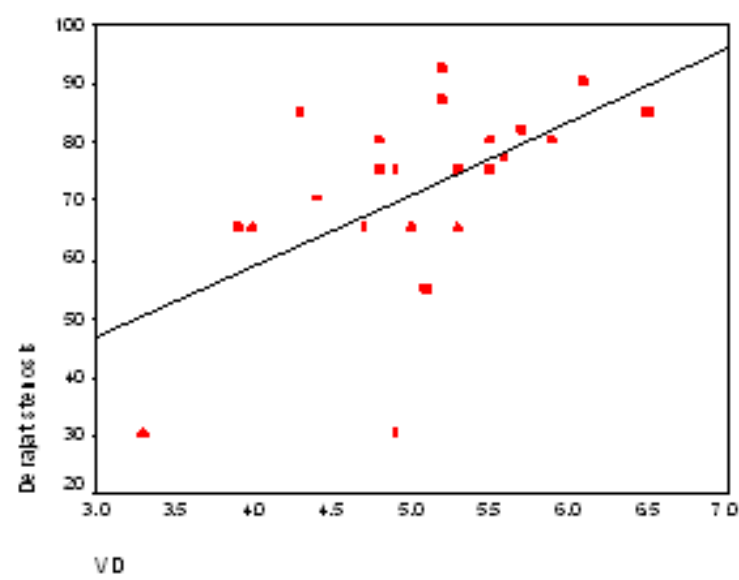

Figure 1. Scatter plot of relationship between degree of stenosis and blood viscosity (BV)

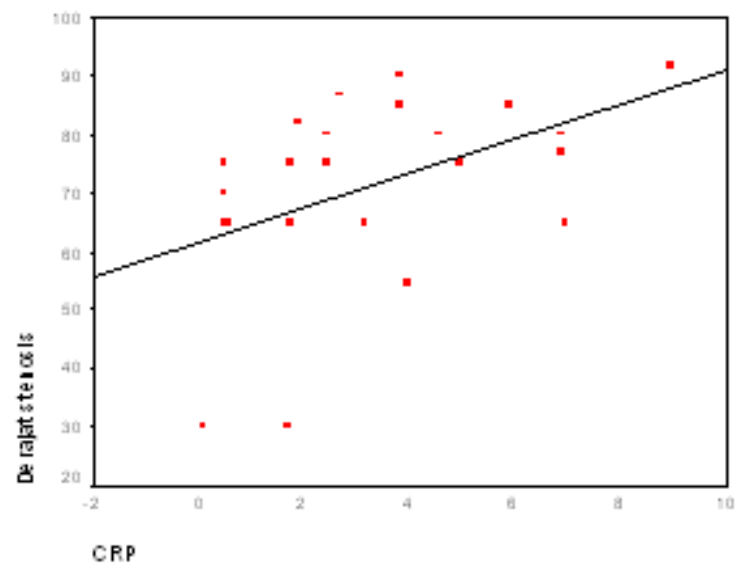

Figure 2. Scatter plot of relationship between degree of stenosis and CRP 
concentration are accompanied by severe degrees of coronary stenosis. From the scatter plot (Figure 2), an increasing trend may be seen between degree of stenosis and blood viscosity.

\section{DISCUSSION}

The positive correlation between DS and BV agrees with the study by Kesmarky et al., ${ }^{(6)}$ who investigated the relationship of hemorheological parameters with severity of coronary artery disease, which was divided into 3 groups, i.e. no significant disease, single vessel disease, and multivessel disease. The investigators found that all hemorheological parameters increased significantly in comparison with controls. Hematocrit and viscosity increased significantly in the group with multivessel disease, in comparison with the groups with no significant disease and single vessel disease.

Blood viscosity plays an important role in the regulation of vascular flow and changes in hemorheological parameters may cause hyperviscosity, thereby supporting the occurrence of occlusive thrombotic events. ${ }^{(7)}$ Blood viscosity as the material determinant of viscoelasticity in direct contact with endothelium may modulate the shape, elasticity, and gene expression of the endothelial cells, and the distribution of adhesion molecules in these cells, and directly affects endothelial cells through shear stress. ${ }^{(18)}$ Increased BV increases the traumatic forces on the endothelial cell walls, thus having a poor impact on endothelial function and playing an important role in the inflammatory process. This condition will also inhibit the production of nitric oxide (NO) through inhibition of the synthesis of endothelial nitric oxide synthase (eNOS) and increases the production of reactive oxigen species (ROS) in endothelial cells and vascular smooth muscle cells. On the other hand, NO has an important role in the regulation of vascular tone, in addition to having strong anti-inflammatory, antiapoptotic, anti-mitogenic, and anti-thrombotic actions. Increased blood viscosity may directly influence wall or endothelial shear stress (ESS), resulting in altered vasomotor tone and decreased ESS as a result of lowered blood flow. ${ }^{(17,18)}$

Increased BV may promote the development of atherosclerosis by increasing platelet adhesion to the subendothelium, increasing protein infiltration into the arterial wall, and changing the shear stress at the site of atherogenesis. ${ }^{(17)}$ In arterial regions with undisturbed flow, physiologically in ESS, the endothelial cells express various atheroprotective genes and repress several pro-atherogenic genes, thus finally leading to stability and undisturbed flow in those regions. By contrast, in regions with low and disturbed flows, at sites of low ESS, the expression of endothelial genes will be modulated by a complex process of mechanoreception and mechanotransduction, thus inducing the atherogenic endothelial phenotype and the early formation of atherosclerotic plaques. ${ }^{(18)}$

Similar results were found in the study by Lee et al. ${ }^{(8)}$ who investigated several hemorheological parameters in subjects with stable angina (SA), unstable angina (UA) and acute myocardial infarction (AMI). On all subjects angiography was performed to establish the diagnosis. The resulting findings as compared to controls showed significant increases in all groups of study subjects, in the order of AMI $>\mathrm{UA}>\mathrm{SA}>$ controls. The conclusion was that there was a relationship between hemorheological abnormalities and severity of coronary artery disease. The investigators showed in their evaluation of intervention therapy to normalize blood rheology, that it could reduce the incidence or progressivity of coronary artery disease ${ }^{(8)}$ Similarly, in the study conducted by Toth et al., ${ }^{(19)} 121$ subjects with coronary artery disease who underwent CT scans of the coronary arteries, were assigned to 4 groups, i.e. those with negative stenosis, with non significant stenosis, with single vessel stenosis and with multi vessel stenosis. The results showed a significant relationship between hematocrit and blood viscosity, which were higher in all groups, in comparison with the negative group. ${ }^{(18)}$ 
The above mentioned correlation between degree of stenosis and CRP is in agreement with the results of the study by Hasnat et al. in which CRP showed a positive significant correlation in 90 subjects with $\mathrm{CHD}$, as determined by vessel score, stenosis score, and extent score. It was concluded from above mentioned study that increases in CRP concentration were substantially correlated with severity and degree of stenosis of CHD. The increase in CRP concentration was associated with cardiovascular disease incidence in the future and may predict coronary atherosclerotic disease. ${ }^{(20)}$

Nyandak et al. ${ }^{(13)}$ also investigated the relationship between CRP and coronary stenosis by angiography and found a positive correlation; whereas if CRP was correlated with angiographic extent score. The CRP concentration was higher in patients with this angiographic degree of stenosis, showing that CRP concentration was correlated with degree of disease severity in patients with CHD. Momiyama et al., ${ }^{(21)}$ Piranfar, ${ }^{(22)}$ Masood et al., ${ }^{(23)}$ and Lai et al., ${ }^{(24)}$ arrived at similar conclusions, namely that CRP is an index of CHD severity and may reflect plaque activity in patients with CHD, and is therefore important for clinical diagnosis and evaluation CHD risk. ${ }^{(21-24)}$ Another study by Ciccone et al. ${ }^{(25)}$ found that thickening of the carotid intima media was correlated with CRP, thus indicating that inflammatory markers affect the progressivity of atherosclerosis in subjects with obstructive sleep apnea. ${ }^{(25)}$

C-reactive protein plays an active role in endothelial dysfunction and the formation and development of atherosclerotic plaques, since it has been found in atherosclerotic plaques. Creactive protein down-regulates the transcription of eNOS protein and messenger ribonucleic acid (mRNA) in endothelial cells, thus resulting in a reduction of NO release. The inhibition of NO facilitates endothelial cell apoptosis and inhibits angiogenesis. Among other proatherogenic effects, CRP regulates intercellular adhesion molecule 1 (ICAM-1), vascular cell adhesion molecule-1 (VCAM-1), and E-selectin. This occurs through up-regulation of the genes by nuclear factor $\kappa-B$ $(\mathrm{NF}-\kappa \mathrm{B})$, which is involved in nuclear transcription of several proatherosclerotic genes and may facilitate leukocyte migration by stimulating the release of monocyte chemotactic protein-1 (MCP-1). In addition, NF- $\mathrm{\kappa B}$ also upregulates angiotensin type-1 receptor (AT-1) to stimulate the migration and proliferation of vascular smooth muscle cells, formation of neointima, and production of ROS. CRP also inhibits the survival and differentiation of bone marrow-derived endothelial progenitor cells and interferes with the maintenance of vascular integrity. Another mechanism in which CRP actively participates is in atheroma formation, i.e. facilitating the opsonization of LDL cholesterol by macrophages to form foam cells. Furthermore, CRP also activates complement, particularly C3, which is found in atherosclerotic lesions and is involved in initiation and progressivity of atherosclerotic plaques. C-reactive protein also induces the production of endothelin-1 as endogenous vasoconstrictor and mediator of endothelial dysfunction, activator of leukocytes and platelets and cellular proliferation. Finally, CRP stimulates the production of IL-6 (interleukin 6) in blood vessels, which is very important since IL-6 is involved in positive feedback for stimulating CRP production in the liver. ${ }^{(26)}$

A limitation of this study was that we did not measure other influencing components such as lipid profile and markers of endothelial dysfunction. Further studies are necessary on the dominant factors affecting endothelial dysfunction, as an extension of the present study. The present study may viewed as preliminary research for the prediction of coronary stenosis events in the community.

\section{CONCLUSIONS}

There was a moderate positive correlation of $\mathrm{BV}$ and CRP with degree of coronary stenosis. Increases in BV and CRP levels will be accompanied by increased severity of coronary stenosis. 


\section{CONFLICT OF INTEREST}

The authors had no conflict interest with any companies in this study. All authors participated in data collection, study design, statistical analysis, and manuscript preparation. All authors gave final consent for the publication.

\section{ACKNOWLEDGMENT}

We wish to express our gratitude to the staff and personnel of the outpatient and inpatient departments of the Cardiac Disease Unit, dr. Kariadi Central Hospital, Semarang, who participated from the start of the study up to the preparation of this paper.

\section{REFERENCES}

1. World Health Organization. Cardiovascular diseases. Geneva: World Health Organization; 2015.

2. Dinas Kesehatan Jawa Tengah. Profil kesehatan Provinsi Jawa Tengah. Dinas Kesehatan. Jawa Tengah. Available at: http://www.dinkes jatengprov.go.id/dokumen/profil/profile2004/ bab5.htm. Accessed March 21, 2014.

3. Suwaida JA, Hamasaki S, Higano ST, et al. Long-term follow-up of patients with mild coronary artery disease and endothelial dysfunction. Circulation 2000;101:948-54.

4. Ganz P, Hsue PY. Endothelial dysfunction in coronary heart disease is more than a systemic process. Eur Heart J 2013;34:2025-7.

5. Froom P. Blood viscosity and the risk of death from coronary heart disease. Eur Heart J 2000; 21:513-4.

6. Kesmarky G, Feher G, Koltai K, et al. Viscosity, hemostasis, and inflammation in atheroscerotic heart diseases. Clin Hemorheol Microcirc 2006; 35:67-73.

7. Cecchi E, Mannini L, Abbate R. Role of hyperviscosity in cardiovascular and microvascular diseases. G Ital Nefrol 2009;26: 20-9.

8. Lee BK, Durairaj A, Mehra A, et al. Hemorheological abnormalities in stable angina and acute coronary syndromes. Clin Hemorheol Microcirc 2008;39:43-51.

9. Libby P, Ridker PM, Hansson GK. Inflammation in atherosclerosis.2009;54:2129-38.
10. Hansson GK, Robertson AK, Soderberg-Naucler C. Inflammation and atherosclerosis. Annu Rev Pathol 2006;1:297-329.

11. Buckley DI, Fu R, Freeman M, et al. C-reactive protein as a risk factor for coronary heart disease: a systemic review and meta-analysis for the US preventive service task force. Ann Intern Med 2009;151:483-95.

12. Kilicarslan A,Uysal A, Roach EC. Acute phase reactants. Acta Medica 2013;2:2-7.

13. Nyandak T, Gogna A, Bansal S, et al. High sensitive C-reactive protein (hs-crp) and its correlation with angiographic severity of coronary artery disease (CAD). JIACM 2007; 8:217-21.

14. Ulucay A, Demirbag R, Yilmaz R, et al. The relationship between plasma c-reactive protein levels and presence and severity of coronary stenosis in patients with stable angina. Angiology 2008;58:657-62.

15. Habib SS, Al Masri AA. Relationship of high sensitivity C-reactive protein with presence and severity of coronary artery disease. Pak J Med Sci 2013;29:1425-9.

16. Ergun CK, Gurel EI, Ozeke O, et al. Blood viscosity changes in slow coronary flow patients. Clin Hemorheol Microcirc 2011;47:27-35.

17. Ridker PM. High-sensitivity C-reactive protein potential adjunct for global risk assessment in the primary prevention of cardiovascular disease. Circulation 2001;103:1813-8.

18. Chatzizisis YS, Coskun AU, Jonas M, et al. Role of endothelial shear stress in the natural history of coronary atherosclerosis and vascular remodeling. JACC 2007;49:2379-93.

19. Toth A, Szukits S, Varady E, et al. Hemorheology parameters in coronary artery disease detected by multi-slice CT. Korea-Australia Rheology J 2014;26:229-35.

20. Hasnat MA, Islam AEMM, Chowdhury AW, et al. High sensitive C-reactive protein (hs-crp) and its correlation with angiographic severity of patient with coronary artery disease (CAD). J Dhaka Med Coll 2010;19:91-7.

21. Momiyama Y, Ohmori R, Fayad ZA, et al. Association between plasma C-reactive protein levels and the severities of coronary and aortic atherosclerosis. J Atheroscler Thromb 2010;17: 460-7.

22. Piranfar MA. The correlation between highsensitivity C-reactive protein (hscrp) serum levels and severity of coronary atherosclerosis. Int Cardiovasc Res J 2014;8:6-8.

23. Masood A, Jafar SS, Akram Z. Serum high sensitivity C-reactive protein levels and the 
severity of coronary atherosclerosis assessed by angiographic Gensini score. J Pak Med Assoc 2011;61:325-7.

24. Lai CL, Ji YR, Liu XH, et al. Relationship between coronary atherosclerosis plaque characteristics and high sensitivity C-reactive proteins, interleukin-6. Chin Med J 2011;124: 2452-6.

25. Ciccone MM, Scicchitano P, Zito A, et al. Correlation between inflammatory markers of atherosclerosis and carotid intima-media thickness in obstructive sleep apnea. Molecules 2014;19:1651-62.

26. Osman RL, Allier PL, Elgharib N, et al. Critical appraisal of C-reactive protein throughout the spectrum of cardiovascular disease. Vasc Health Risk Manag 2006:2:221-37.

27. Dawson B, Trapp RG. Basic \& Clinical Biostatistics. $4^{\text {th }}$ ed. New York: Lange Medical Books/McGraw-Hill;2004. 